\title{
Influence of Body and Head Posture on Deviation of the Incisal Point Undergoing Dental Treatment
}

\author{
Mami Ishii, DDS, PhD, ${ }^{a}$ Kaoru Koide, DDS, PhD, ${ }^{b}$ Makoto Ueki, DDS, PhD, ${ }^{b}$ \\ and Naoki Asanuma, DDS, PhD $^{\mathrm{C}}$ \\ ${ }^{a}$ Comprehensive Dental Care, Niigata Hospital, The Nippon Dental University, Niigata, Japan \\ ${ }^{b}$ Department of Removable Partial Denture, The Nippon Dental University School of Life Dentistry at Niigata, \\ Niigata, Japan \\ c Junior Collage at Niigata, The Nippon Dental University, Niigata, Japan
}

\section{Clinical significance}

In order to establish patient posture standards for use in the clinic, the present research considered the influence on mandibular position of the head and body posture of patients undergoing dental treatment.

\begin{abstract}
Purpose: The objectives of this study were to determine how changes in body and head position undergoing dental treatment affect mandibular position, and to develop a set of standards for patient posture.

Methods: Mandibular position was investigated in 8 subjects with normal occlusion and not suffering any stomatognathic dysfunction. This was done by measuring the location of the tapping point on the incisal point using a Gnathohexagraph (a 3-dimensional jaw movement measurement device with 6 degrees of freedom), with the subject's head in 4 different positions while sitting, and the body and head in 16 different positions with the subject supine, and then comparing deviation from the reference position in each of these positions. Statistical analysis of data was performed using first, repeated measures of 1-way ANOVA $(\alpha=.05)$, second Bonferroni's multiple comparison test was undertaken in seated positions. In supine positions, repeated measures of 2-way ANOVA was performed, and followed by Bonferroni's multiple comparison test was performed.
\end{abstract}

Results: The incisal point deviated significantly in the anteroposterior direction due to changes in head and body position. With the subjects seated, the incisal point tended to move backwards when the subjects were asked to lean backwards from the reference position. The incisal point tended to move forward when the subjects were asked to lean forward. With the

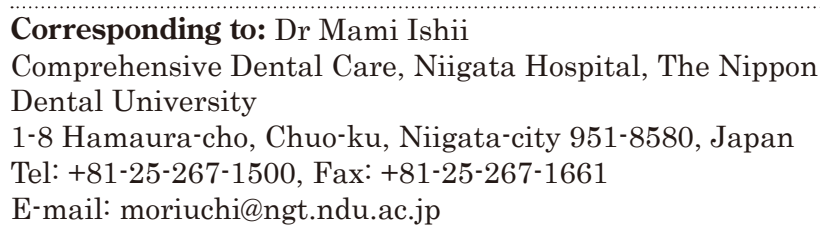

Received on December 14, 2006 / Accepted on June 5, 2007 subjects in a supine position, the incisal point was inclined backwards. The degree of backwards inclination of the incisal point tended to decline as the head position was varied from 10 degrees backwards to $20 \mathrm{de}^{-}$ grees forward, regardless of the degree of backwards inclination of the body.

Conclusion: Changes in body and head posture undergoing dental treatment affect incisal point deviation.

Key words: body posture, head posture, incisal point, Gnathohexagraph, natural head position

\section{Introduction}

Recommended postures for patients undergoing dental procedures vary according to the specifics of the treatment and procedures involved. One report ${ }^{1}$ suggests that mandibular inclination due to the backward tilting of the body must be avoided in patients for whom an occlusal registration is being made or those who are undergoing occlusal adjustment. On the other hand, the horizontal position is also said to be useful since it reduces position variability and causes minimal psychophysiologic stress for the dentist providing dental treatment. ${ }^{2}$ Definitive standards for patient body and head position have yet to be established.

It has been reported that changes in the position of the body and head affect mandibular position, movement, and function, as well as the activity of the head and neck muscles. ${ }^{1,3-13}$ However, the paucity of research in this area under clinical conditions indicates that there is an inadequate understanding of the effects on mandibular position in the body and head positions patients may assume during dental procedures. In addition, there is no literature identified on the effects of head posture on mandibular position in supine 
patients; there is also no detailed investigation of the interrelationship between body and head postures.

The present research was conducted to establish standards for patient postures during dental procedures, with particular emphasis on postures during occlusal registration and occlusal adjustment. We considered the effect that body and head positions have on mandibular position by measuring the extent of deviations in tapping points at the incisal point.

\section{Materials and methods}

The study was approved by the Ethics Committee of the Nippon Dental University at Niigata. The subjects- 7 men and 1 woman-with normal occlusion and no stomatognathic dysfunction were fully informed of the main aims of the research and provided informed consent to participate. The participants' ages ranged from 22 to 27 years, with a mean age of 24 years.

A 3-dimensional jaw movement measurement device with 6 degrees of freedom (Gnathohexagraph JM1000; Ono Measurement Devices, Tokyo, Japan) was used to measure the amount of deviation in mandibular position. According to the procedures of Nishimaki et $\mathrm{al}^{1}$ and Saito et $\mathrm{al},{ }^{16}$ the upper and lower face-bow components of Gnathohexagraph were secured with a cyanoacrylate instant adhesive (Dental Cyanon; Koatsu Gas Kogyo, Tokyo, Japan) to the labial surface of the maxillary and mandibular teeth using a clutch constructed by the authors specifically for this project (Fig. 1). The authors fabricated stationary and moving portions of a Gnathohexagraph camera stand and modified the stand to allow measurement in all possible body and head positions (Fig. 2).

The subjects were fitted with an anterior occlusal positioning device by using an autopolymerizing resin (Unifast II; GC, Tokyo, Japan) on a diagnostic cast attached to an articulator. The amount of bite raising was assumed to be minimal when tooth contact was avoided; it become less than $3 \mathrm{~mm}$ at the incisal point. A plane parallel to the occlusal plane was set between $2 \mathrm{~mm}$ before and $3 \mathrm{~mm}$ behind the tapping point in the natural head position on the surface of the anterior occlusal positioning device.

The parts for adjusting the angle of the back and headrest of a dental chair were modified to

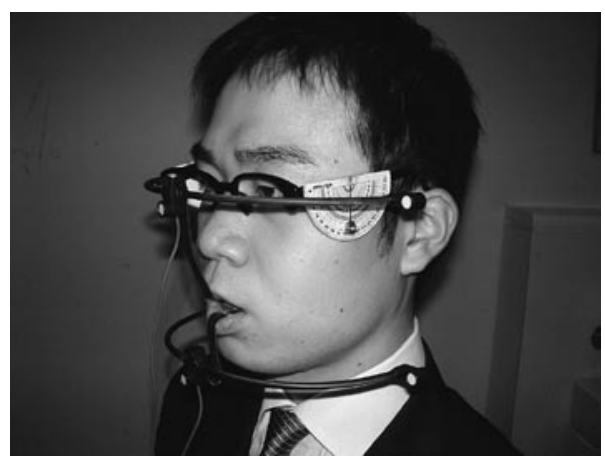

Fig. 1 Head inclination measurement device made by authors and facebow secured to teeth using clutch.

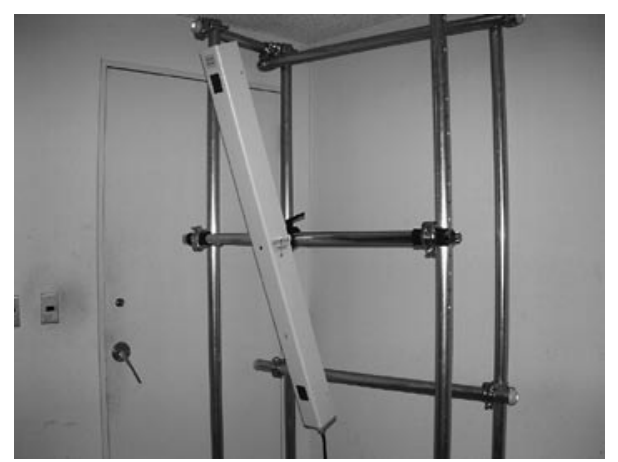

Fig. 2 Camera stand for Gnathohexagraph by authors.

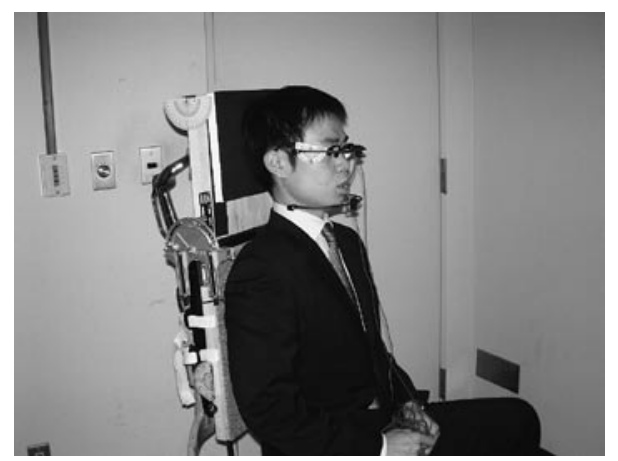

Fig. 3 Back and headrest of dental chair with bending leg portion that allows for accurate angular adjustments.

allow accurate angular adjustment with the body and head in clinical positions (Fig. 3). The procedure used was as follows. The subjects were seated in the dental chair with its back perpendicular to the floor and asked to adopt a natural head position. ${ }^{14,15}$ The location of the spinous process of the $\mathrm{C} 7$ vertebra was determined from behind and marked, and the vertical position of the hinge between the back and the headrest was brought to this position. The subjects were then fitted with the head inclination measurement device constructed by the authors (Fig. 1) and asked to 
Table 1 Measurement conditions.

\begin{tabular}{|c|c|c|c|c|}
\hline & Body Position & Head Position & & Total \\
\hline \multirow{4}{*}{ Sitting Position } & \multirow{4}{*}{0 degrees } & 10 degrees backward & & \\
\hline & & 0 degrees (Reference Position) & & \\
\hline & & 10 degrees forward & & \\
\hline & & 20 degrees forward & 4 conditions & \\
\hline \multirow{4}{*}{ Supine Position } & 50 degrees & 10 degrees backward & & \\
\hline & 60 degrees & 0 degrees & & \\
\hline & 70 degrees & 10 degrees forward & & \\
\hline & 80 degrees & 20 degrees forward & 16 conditions & 20 conditions \\
\hline
\end{tabular}

adopt a natural head position, which was taken to be the reference position (body position of 0 degrees and head position of 0 degrees).

There were 4 head positions: 0 degrees with no tilting from the natural head position, and the headrest tilted backward 10 degrees or forward 10 degrees or 20 degrees from the 0 -degree reference position. There were 5 body positions: 0 degrees with the back of the chair perpendicular to the floor and 50, 60, 70, and 80 degrees backward from the 0 -degree reference position. These 4 head and 5 body positions were combined for a total of 20 positions at which measurements were performed.

Only the head position was varied from the established reference position in order to study the effects of head position in seated subjects. These 4 positions were considered to be the seated positions in the project. Next, 4 positions with the body tilted backward were combined with the 4 head positions for a total of 16 positions to study the effects of head position alone and the combined effects of body and head positions in supine subjects. These positions were taken to be the supine positions in the research (Table 1) (Fig. 4).

The Frankfurt plane was adopted as the reference plane for the Gnathohexagraph measurement, and the incisal point was used as the measurement point. The measurement system was set up in an unlit sealed room ${ }^{1,16}$ in order that a light-emitting diode (LED) at the center of the upper face-bow and 2 charge-coupled device (CCD) cameras located at the top and bottom of Gnathohexagraph remained equidistantly spaced. ${ }^{1,16}$ The distance from the LED to the center of the cameras' frames was held constant at $0.8 \mathrm{~m}$, and the camera frames were positioned perpendicular to the face-bow ${ }^{1,16}$ (Fig. 4).

The subjects were first asked to thoroughly practice the tapping movement; the frequency of

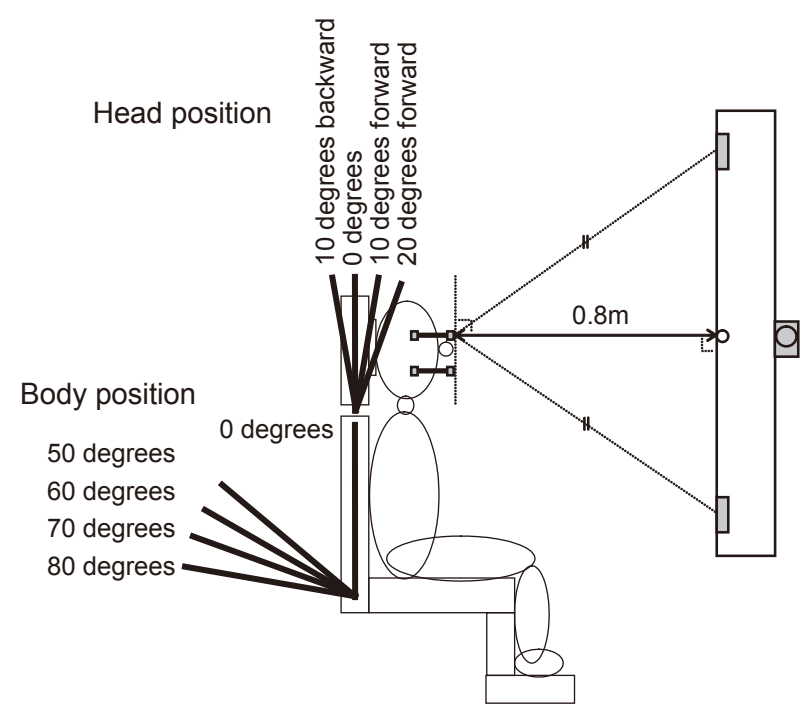

Fig. 4 Measurement conditions.

strokes was 1.5 times per second, and the opening of the mouth was approximately $10 \mathrm{~mm}$. The subjects were then asked to close their mouths with their muscles relaxed. The measurements were begun when the edges of the mandibular central incisors were at rest against the plane positioned on the anterior occlusal positioning device. Three seconds after the beginning of measurement, mandibular motion was photographed as the subjects tapped 10 times while the opening of their mouths was approximately $10 \mathrm{~mm}$. Measurements were performed 3 times for each of the 20 positions.

The $\mathrm{x}$-axis coordinates indicating the anteroposterior direction (positive for forward), the $\mathrm{y}^{-}$axis coordinates indicating the horizontal direction (positive for left), and the $\mathrm{z}$-axis coordinates indicating the vertical direction (positive for upward) were determined from the 3-dimensional coordinates of the position of the mandible with the incisal point in the uppermost position on the 
Table 2 Mean and SD of positional deviation in $\mathrm{x}, \mathrm{y}$, and $\mathrm{z}$ axis $(\mathrm{n}=8)$.

\begin{tabular}{|c|c|c|c|c|c|c|c|c|}
\hline & & & \multirow{2}{*}{$\begin{array}{c}\text { Sitting Position } \\
\text { Body Position }\end{array}$} & \multicolumn{5}{|c|}{ Supine Position } \\
\hline & & & & \multicolumn{4}{|c|}{ Body Position } & \multirow[b]{2}{*}{ Total } \\
\hline & & & 0 degrees & 50 degrees & 60 degrees & 70 degrees & 80 degrees & \\
\hline \multirow{4}{*}{ 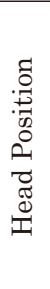 } & $\begin{array}{l}10 \text { degrees } \\
\text { backward }\end{array}$ & $\begin{array}{c}\text { mean } \\
(\mathrm{SD})\end{array}$ & $\begin{array}{l}-0.38 \\
(0.38) \\
\end{array}$ & $\begin{array}{c}-1.00 \\
(0.77)\end{array}$ & $\begin{array}{c}-1.13 \\
(0.79) \\
\end{array}$ & $\begin{array}{c}-0.99 \\
(0.72) \\
\end{array}$ & $\begin{array}{c}-1.29 \\
(0.85) \\
\end{array}$ & $\begin{array}{c}-1.1 \\
(0.76) \\
\end{array}$ \\
\hline & 0 degrees & $\begin{array}{c}\text { mean } \\
\text { (SD) }\end{array}$ & $\begin{array}{l}- \\
- \\
\end{array}$ & $\begin{array}{c}-1.05 \\
(0.80) \\
\end{array}$ & $\begin{array}{c}-0.96 \\
(0.51) \\
\end{array}$ & $\begin{array}{c}-0.97 \\
(0.81) \\
\end{array}$ & $\begin{array}{c}-1.04 \\
(0.79) \\
\end{array}$ & $\begin{array}{c}-1.01 \\
(0.70) \\
\end{array}$ \\
\hline & $\begin{array}{c}10 \text { degrees } \\
\text { forward }\end{array}$ & $\begin{array}{c}\text { mean } \\
\text { (SD) }\end{array}$ & $\begin{array}{c}0.32 \\
(0.67) \\
\end{array}$ & $\begin{array}{c}-0.54 \\
(1.04)\end{array}$ & $\begin{array}{c}-0.68 \\
(1.07) \\
\end{array}$ & $\begin{array}{c}-0.81 \\
(1.02)\end{array}$ & $\begin{array}{c}-1.04 \\
(0.97) \\
\end{array}$ & $\begin{array}{c}-0.77 \\
(0.99) \\
\end{array}$ \\
\hline & $\begin{array}{l}20 \text { degrees } \\
\text { forward }\end{array}$ & $\begin{array}{l}\text { mean } \\
\text { (SD) }\end{array}$ & $\begin{array}{c}0.49 \\
(0.51)\end{array}$ & $\begin{array}{c}-0.26 \\
(0.84)\end{array}$ & $\begin{array}{c}-0.68 \\
(0.79)\end{array}$ & $\begin{array}{c}-0.49 \\
(1.02)\end{array}$ & $\begin{array}{c}-0.50 \\
(1.09)\end{array}$ & $\begin{array}{c}-0.48 \\
(0.91)\end{array}$ \\
\hline
\end{tabular}

\begin{tabular}{|c|c|c|c|c|c|c|c|c|}
\hline \multicolumn{9}{|c|}{ Mean SD of positional deviation along y axis (mm) } \\
\hline & & & \multirow{2}{*}{$\begin{array}{c}\text { Sitting Position } \\
\text { Body Position }\end{array}$} & \multicolumn{5}{|c|}{ Supine Position } \\
\hline & & & & \multicolumn{4}{|c|}{ Body Position } & \multirow[b]{2}{*}{ Total } \\
\hline & & & 0 degrees & 50 degrees & 60 degrees & 70 degrees & 80 degrees & \\
\hline \multirow{4}{*}{ 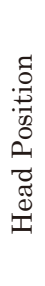 } & $\begin{array}{l}10 \text { degrees } \\
\text { backward }\end{array}$ & $\begin{array}{c}\text { mean } \\
(\mathrm{SD})\end{array}$ & $\begin{array}{c}0.09 \\
(0.37) \\
\end{array}$ & $\begin{array}{c}0.05 \\
(0.39) \\
\end{array}$ & $\begin{array}{c}0.11 \\
(0.34) \\
\end{array}$ & $\begin{array}{c}0.15 \\
(0.30) \\
\end{array}$ & $\begin{array}{c}0.09 \\
(0.29) \\
\end{array}$ & $\begin{array}{r}0.10 \\
(0.32) \\
\end{array}$ \\
\hline & 0 degrees & $\begin{array}{l}\text { mean } \\
(\mathrm{SD})\end{array}$ & $\begin{array}{l}- \\
- \\
\end{array}$ & $\begin{array}{c}0.04 \\
(0.31) \\
\end{array}$ & $\begin{array}{c}0.10 \\
(0.33) \\
\end{array}$ & $\begin{array}{c}0.18 \\
(0.39) \\
\end{array}$ & $\begin{array}{c}0.18 \\
(0.37) \\
\end{array}$ & $\begin{array}{c}0.13 \\
(0.34) \\
\end{array}$ \\
\hline & $\begin{array}{l}10 \text { degrees } \\
\text { forward }\end{array}$ & $\begin{array}{c}\text { mean } \\
\text { (SD) }\end{array}$ & $\begin{array}{l}-0.12 \\
(0.24)\end{array}$ & $\begin{array}{c}-0.14 \\
(0.34)\end{array}$ & $\begin{array}{c}-0.05 \\
(0.36)\end{array}$ & $\begin{array}{c}0.01 \\
(0.42)\end{array}$ & $\begin{array}{c}-0.05 \\
(0.26)\end{array}$ & $\begin{array}{r}-0.06 \\
(0.34)\end{array}$ \\
\hline & $\begin{array}{l}20 \text { degrees } \\
\text { forward }\end{array}$ & $\begin{array}{c}\text { mean } \\
\text { (SD) }\end{array}$ & $\begin{array}{l}-0.13 \\
(0.34)\end{array}$ & $\begin{array}{c}-0.11 \\
(0.40) \\
\end{array}$ & $\begin{array}{c}-0.06 \\
(0.31)\end{array}$ & $\begin{array}{c}-0.09 \\
(0.32)\end{array}$ & $\begin{array}{c}-0.12 \\
(0.29)\end{array}$ & $\begin{array}{r}-0.09 \\
(0.32) \\
\end{array}$ \\
\hline
\end{tabular}

\begin{tabular}{|c|c|c|c|c|c|c|c|c|}
\hline \multicolumn{9}{|c|}{ Mean SD of positional deviation along $\mathrm{z}$ axis $(\mathrm{mm})$} \\
\hline & & & \multirow{2}{*}{$\begin{array}{c}\text { Sitting Position } \\
\text { Body Position }\end{array}$} & \multicolumn{5}{|c|}{ Supine Position } \\
\hline & & & & \multicolumn{4}{|c|}{ Body Position } & \multirow[b]{2}{*}{ Total } \\
\hline & & & 0 degrees & 50 degrees & 60 degrees & 70 degrees & 80 degrees & \\
\hline \multirow{4}{*}{ 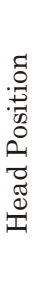 } & $\begin{array}{l}10 \text { degrees } \\
\text { backward }\end{array}$ & $\begin{array}{l}\text { mean } \\
\text { (SD) }\end{array}$ & $\begin{array}{c}0.04 \\
(0.24)\end{array}$ & $\begin{array}{c}0.17 \\
(0.44)\end{array}$ & $\begin{array}{c}0.14 \\
(0.48)\end{array}$ & $\begin{array}{c}0.14 \\
(0.44)\end{array}$ & $\begin{array}{c}0.11 \\
(0.44)\end{array}$ & $\begin{array}{c}0.14 \\
(0.43)\end{array}$ \\
\hline & 0 degrees & $\begin{array}{l}\text { mean } \\
(\mathrm{SD})\end{array}$ & $\begin{array}{l}- \\
- \\
\end{array}$ & $\begin{array}{c}0.13 \\
(0.34) \\
\end{array}$ & $\begin{array}{c}0.10 \\
(0.36) \\
\end{array}$ & $\begin{array}{c}0.12 \\
(0.41) \\
\end{array}$ & $\begin{array}{c}0.10 \\
(0.41) \\
\end{array}$ & $\begin{array}{c}0.11 \\
(0.36) \\
\end{array}$ \\
\hline & $\begin{array}{l}10 \text { degrees } \\
\text { forward }\end{array}$ & $\begin{array}{c}\text { mean } \\
(\mathrm{SD})\end{array}$ & $\begin{array}{l}-0.04 \\
(0.11) \\
\end{array}$ & $\begin{array}{c}0.10 \\
(0.37) \\
\end{array}$ & $\begin{array}{c}0.12 \\
(0.28) \\
\end{array}$ & $\begin{array}{c}0.15 \\
(0.34) \\
\end{array}$ & $\begin{array}{c}0.23 \\
(0.32) \\
\end{array}$ & $\begin{array}{r}0.15 \\
(0.32) \\
\end{array}$ \\
\hline & $\begin{array}{c}20 \text { degrees } \\
\text { forward }\end{array}$ & $\begin{array}{l}\text { mean } \\
(\mathrm{SD})\end{array}$ & $\begin{array}{l}-0.01 \\
(0.28)\end{array}$ & $\begin{array}{c}0.18 \\
(0.27)\end{array}$ & $\begin{array}{c}0.17 \\
(0.22)\end{array}$ & $\begin{array}{c}0.11 \\
(0.13)\end{array}$ & $\begin{array}{c}0.16 \\
(0.25)\end{array}$ & $\begin{array}{c}0.15 \\
(0.21)\end{array}$ \\
\hline
\end{tabular}

path of closure during 10 repetitions of tapping movements for each position. The mean values of data obtained over these repetitions were calculated. This was repeated 3 times, and the mean values of the 3 repetitions determined and regarded as the coordinates for each position. The differences in the $\mathrm{x}^{-}, \mathrm{y}^{-}$, and $\mathrm{z}^{-}$-axis coordinates for each position from the reference position were calculated and represented the amount of deviation in the incisal point of each subject. The mean values for the 8 subjects and the standard deviations were also determined.

Statistical analysis of the data was performed using a computerized statistical software package (SPSS; SPSS Inc, Chicago, Ill) at $\alpha=.05$. First, a repeated-measures 1-way ANOVA was performed on the $\mathrm{x}^{-}, \mathrm{y}^{-}$, and $\mathrm{z}^{-}$axes of the Gna- thohexagraph. Second, Bonferroni's multiple comparison test was performed for the seated positions. A repeated-measures 2-way ANOVA was performed for the supine positions with body and head positions as factors, followed by a multiple comparison test performed on factors for which significance was noted.

\section{Results}

The mean values and standard deviations of the degree of deviation in the $\mathrm{x}^{-}, \mathrm{y}^{-}$, and $\mathrm{z}^{-}$axes of Gnathohexagraph at each measurement position are listed in Table 2. Statistical analysis of the $\mathrm{x}^{-}, \mathrm{y}^{-}$, and $\mathrm{z}^{-}$axis position data indicated a significant difference among the positions along 
Table 3 Result of 2-way ANOVA with subject supine along $\mathrm{x}$ axis $(\mathrm{n}=8)$.

\begin{tabular}{rrrccc}
\hline \multicolumn{1}{c}{ factor } & SS & df & MS & F & P \\
\hline A: Body Position & 1.054 & 3 & 0.351 & 1.948 & .153 \\
error & 3.788 & 21 & 0.180 & & \\
\hline B: Head Position & 7.335 & 3 & 2.445 & 6.073 & $.004^{* *}$ \\
error & 8.455 & 21 & 0.403 & & \\
\hline A $\times \mathrm{B}$ & 1.259 & 9 & 0.140 & 0.757 & .656 \\
error & 11.646 & 63 & 0.185 & & \\
\hline & & & & & $* *: P<.01$
\end{tabular}

the $\mathrm{x}^{-}$-axis but no significant difference among $\mathrm{po}^{-}$ sitions along the $\mathrm{y}^{-}$or $\mathrm{z}$-axis; therefore, only the $\mathrm{x}$-axis results have been presented.

Figure 5 presents the mean degrees of anteroposterior deviation and the standard deviations in the incisal point with the subject seated and shows the results of Bonferroni's multiple comparison test. Forward tilting of the head tended to cause forward inclination of the incisal point, while backward tilting of the head tended to cause backward incisal point inclination. A multiple comparison test revealed a significant difference in the incisal point position with the head inclined 10 degrees backward to 10 degrees forward $(P=.019)$ and with the head inclined 10 degrees backward to 20 degrees forward $(P=.003)$. The results of the 2-way ANOVA, with head and body positions as factors, for the 16 positions with the subjects supine are shown in Table 3. It was found that body position was irrelevant to incisal point position, while the interaction between body and head positions had a significant effect $(P=.004)$.

Figure 6 shows the mean degrees of anteroposterior deviation in the incisal point and standard deviations, with the subjects supine and assuming the 4 body positions. Figure 7 shows the mean degrees of anteroposterior deviation in the incisal point and standard deviations, with the subjects supine and assuming the 4 head positions, and the results of Bonferroni's multiple comparison test, with head position as the factor. The degree of backward mandibular inclination tended to decrease as the head was successively moved from 10 degrees backward to 0 degrees, 10 degrees forward, and 20 degrees forward. The multiple comparison test revealed a significant difference in incisal point position with the head inclined 10 degrees backward to 20 degrees forward $(P=.001)$ and 0 degrees to 20 degrees forward $(P=.000)$.

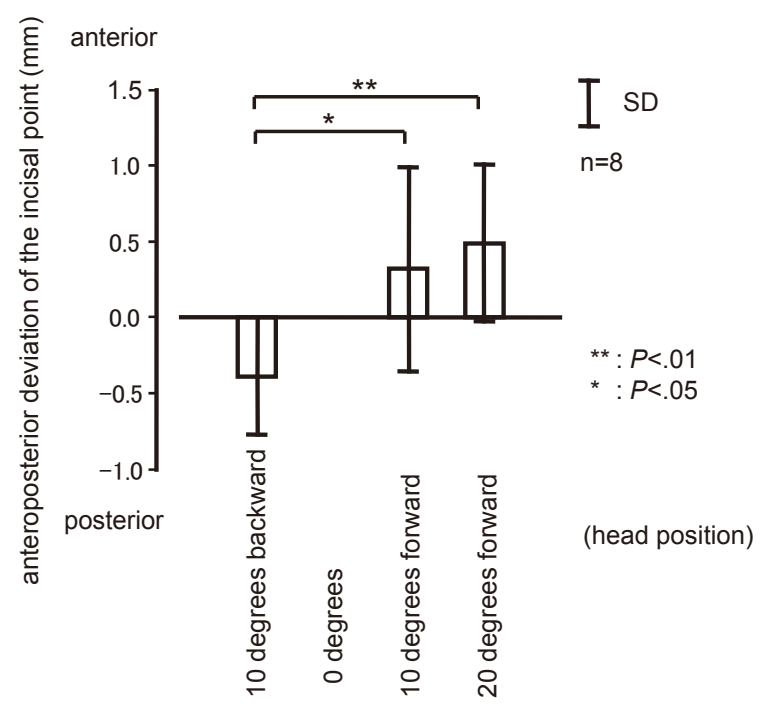

Fig. 5 Effects of head position with subjects seated (x axis).

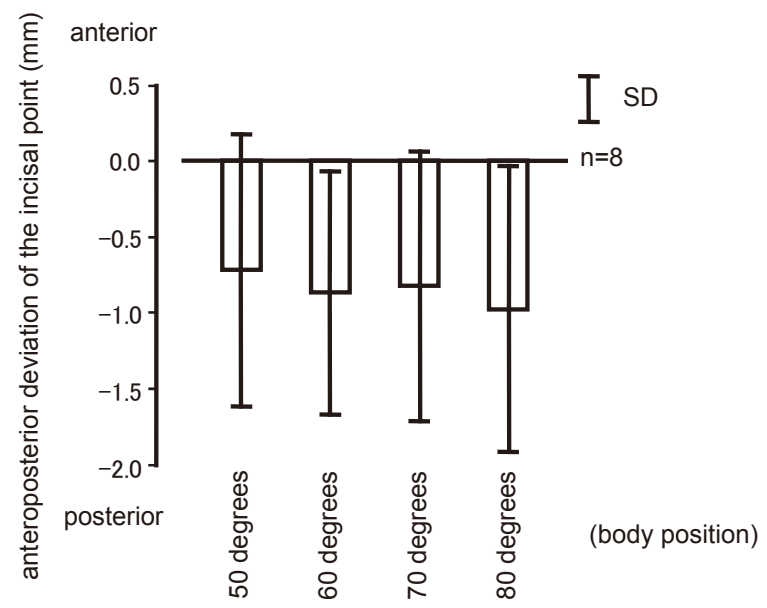

Fig. 6 Effects of body position with subjects supine (x axis).

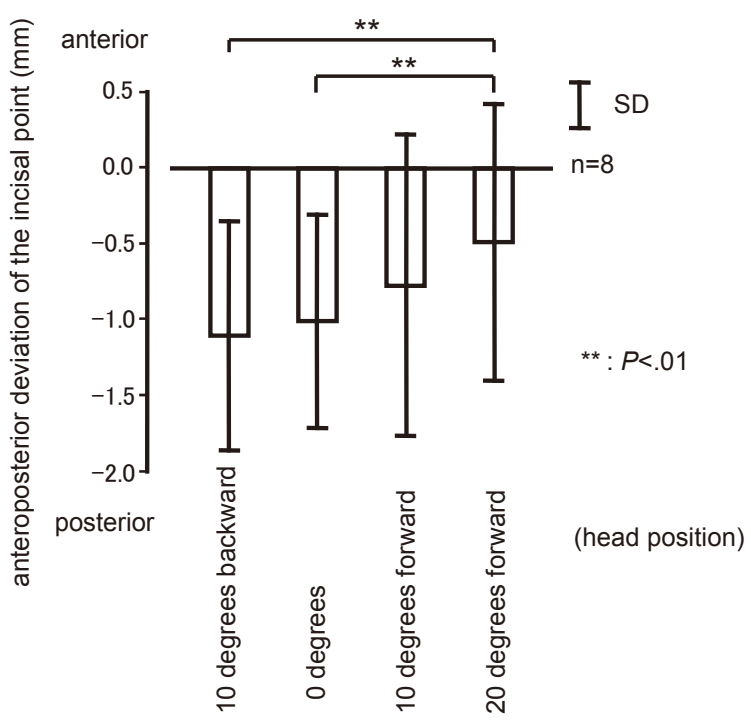

Fig. 7 Effects of head position with subjects supine (x axis). 


\section{Discussion}

The precision of the measuring equipment and methodology used in the present research was verified by Nishimaki et $\mathrm{al}^{1}$ and Saito et al. ${ }^{16}$ The upper and lower face-bow components of Gnathohexagraph were fixed to the teeth using a clutch. The position of an LED at the center of the upper face-bow and 2 CCD cameras of Gnathohexagraph was kept constant even if the body and head postures changed. In addition, the measurement was performed in an unlit sealed room. Thus, in this study, even a minor deviation in mandibular position was measured with precision.

The subjects were fitted with an anterior occlusal positioning device to avoid restriction by the teeth; as a result, free tapping depending on subjects' ability became possible. There are some other methods to avoid restriction by the teeth, for example, Gothic arch tracing and occlusal splints. If using intraoral Gothic arch tracing in a non-edentulous subjects does not allow free movement of the tongue, there is a possibility of causing mandiblar deviation. While using an occlusal splint, it is difficult to set the plane of splint such that all teeth are in contact with it while the mandible moves. Therefore, the anterior occlusal positioning device used in the present research was selected to be the best method subjects could perform free tapping corresponding the deviation of the mandible.

The body and head postures of the subjects seated and in a supine position were those assumed during standard dental procedures over the adjustable range of an actual dental chair. With regard to body posture, one report ${ }^{1}$ states that the mandible tends to move significantly backward when the body is inclined backward to 45 degrees or greater. Based on this finding, 4 positons from a 50- to 80-degree backward inclination were used with the subjects in a supine position.

Although the supine position is an inevitable consequence of dental treatment, ${ }^{2}$ it is thought that the mandible deviates backward in this position. However, there is a lack of literature on research in which the body and head postures of seated and supine subjects are set at a variety of angles to determine the interrelationship between these 2 factors. The positions used in the present research were appropriate for the investigation of patient postures in that they allowed for clinically allowable deviation in mandibular position, even in supine subjects, and can be used as indexes in actual dental treatment.

When changing the head position of subjects by adjusting the headrest, it was considered necessary to establish headrest positions under fixed, reproducible conditions. There are 7 cervi- $^{-}$ cal vertebrae that move when the position of the head is changed, due to the action of connected muscles and ligaments. Most of the muscles and ligaments of the rear neck associated with forward and backward movement of the head are connected to the $\mathrm{C} 6$ and $\mathrm{C} 7$ vertebrae. The C7 vertebra, the fixed pivot around which this movement revolves, is the most affected by movement. ${ }^{9}$ The dental chair was adjusted so that the movable portion of the headrest corresponded to this location in each subject.

Studies have indicated that forward and backward tilting of the head affects the anteroposterior position of the mandible. ${ }^{4,5,7-12}$ Regarding the results of anteroposterior, horizontal, and vertical measurements in the present study, significant differences in mandibular position were noted in the anteroposterior measurements but not in horizontal or vertical measurements. It is thought that there was no large vertical deviation in the incisal point on the anterior occlusal positioning device because a plane parallel to the occlusal plane was provided.

In this project, relatively small changes in the head position were found to cause deviation in the incisal point, which may have been due to physical and anatomical effects. The results indicate that the degree of head inclination tends to be proportionate to the degree of deviation in the incisal point and is therefore unlikely to be the result of postural reflexes. It is thought that when subjects held their heads back, the mandible tended to move backward under the force of gravity and the pull of the anterior neck muscles. With the head forward, the mandible tended to move forward due to gravity and the pull from submaxillary tissue, muscles, and other soft tissues. Because the position of the mandible can deviate anteroposteriorly due to small changes in the head position of seated patients, the position of the head must be closely monitored in patients undergoing occlusal registration recordings or occlusal adjustment, and it is important to use the natural head position as the reference position.

The incisal point showed a tendency to deviate backward in supine patients whose bodies were 
tilted backward at 50 degrees to 80 degrees. It is believed that the effects of gravity on the mandible, muscles of mastication, the upper muscles of the hyoid, the lower muscles of the hyoid, the platysma muscle, and the skin and ligaments play a large role in causing backward deviation of the mandible in supine patients. ${ }^{1,6,7}$ Conversely, when the head was inclined forward, the backward tug of the neck muscles, skin, and other tissues on the mandible is reduced. This causes a change in the equilibrium between gravity and these tissues, resulting in a consequent suppression of the backward deviation of the mandible.

However, there has been no detailed published report on studies performed on supine subjects for whom body and head positions were varied and in which the interrelationship between head and body positions was monitored in terms of the amount of deviation in mandibular position. The present research gradually varied head and body positions over 16 standard positions, and detailed comparisons were made. Two-way ANOVA revealed that anteroposterior changes in head position had a large effect on the amount of deviation in mandibular position, regardless of the degree of backward inclination in the body position of supine subjects. Sekine et $\mathrm{al}^{7}$ reported that the influence of inclination of the axis of the head on mandibular position is at least as great as the effect of inclination of the axis of the body. The present research supports this finding.

Although a supine position is highly useful and, indeed, indispensable for both patients and dentists, it has been shown that the backward inclination of the body results in a large degree of backward inclination in mandibular position. However, the findings of this study suggest that head position, in particular, should be adequately considered when providing dental treatment to patients in a supine position, and that forward tilting of the head in order to prevent tug of the anterior neck muscles and other soft tissues is an effective way of suppressing backward deviation in mandibular position. If backward deviation in mandibular position cannot be avoided, such as during occlusal registration recording or occlusal adjustment, this deviation can be kept within an allowable range by adequately tilting the head forward with a patient in the supine position. A study performed on a larger scale is recommended to corroborate the findings of this study. Further, these findings hint at the importance of seating patients in the final stages of occlusal registration recording or occlusal adjustment and asking them to maintain a natural head position.

\section{Conclusion}

Within the limitations of this study, it was found that the incisal point deviated significantly in the anteroposterior direction due to changes in body and head positions. With the subjects in a seated position, the incisal point tended to move backward when the subjects were asked to lean backward from the reference position and tended to move forward when the subjects were asked to lean forward. With the subjects in a supine position, the incisal point was inclined backward. The degree of backward inclination of the incisal point tended to decline as the head position was varied from backward to forward, regardless of the degree of backward inclination of the body.

\section{References}

1. Nishimaki J, Koide K, Ueki $\mathrm{M}$ et al. A clinical study on changes of mandibular position due to posture during dental treatment. J Jpn Prosthodont Soc 46: 64-72, 2002.

2. Colangelo G, Belenky MM. Performance Logic: A key to improving dental practice. J Dent Pract Adm 7: 173-177, 1990.

3. Cohen S. A cephalometric study of rest position in edentulous persons. Influence of variations in head position. J Prosth Dent 7: 467-472, 1957.

4. Silverman MM. Centric occlusion and jaw relations and fallacies of current concepts. J Prosth Dent 7: 750-769, 1957.

5. Preiskel HW. Some observations on the postural position of the mandible. J Prosth Dent 15: 625-633, 1965.

6. McLean LF, Brenman HS, Friedman MGF. Effects of changing body position on dental occlusion. J Dent Res 52: 1041-1045, 1973.

7. Sekine H, Kishi M. Experimental studies on Influences of sagittal inclination of body axis and head axis on the stability of the mandibular position. Bull Tokyo dent Coll 20: 135-143, 1979.

8. Mohl ND. V The role of head posture in mandibular function. In: Solberg WK, Clark GT, editor, Abnormal Jaw Mechanics, Diagnosis and Treatment 97-116, Chicago: Quintessence, 1984.

9. Goldstein DF, Kraus SL, Williams WB. Influence of cervical posture on mandibular movement. J Prosthet Dent 52: 421-426, 1984.

10. Winnberg A, Pancherz H, Westesson PL. Head posture and hyo-mandibular function in man. A 
synchronized electromyographic and videofluorographic sutudy of the open-close-clench cycle. Am J Orthod Dentofacial Orthop 94: 393-404, 1988.

11. Chapman RJ, Maness WL, Osorio J. Occlusal contact variation with changes in head position. Int $\mathrm{J}$ Prosthodent 4: 377-381, 1991.

12. Rahman M, Kohno S, Sawada K et al. Head position affects the antero-posterior location of tapping points. J Jpn Soc Stomatognath Funct 8: 1-6, 2001.

13. Tingey EM, Buschang PH, Throckmorton GS. Mandibular rest position: a reliable position in- fluenced by head support and body posture. Am J Orthod Dentofacial Orthop 120: 614-622, 2001.

14. Ota A, Hatate S. A study on the horizontal reference plane in prosthodontics-establishment of the anterior reference point-. Shigaku 77: 1470-1483, 1989. (in Japanese)

15. Chiu CS, Clark RK. Reproducibility of natural head position. J Dent. 19: 130-131, 1991.

16. Saito T, Koide K, Asanuma $\mathrm{N}$ et al. Influence of bringing the angle of the mouth back by straining facial muscles on the mandibular position. J Jpn Prosthodont Soc 46: 195-202, 2002. 